\title{
PRZYJMOWANIE DO KLASZTORÓW ŻOŁNIERZY I MAŁ̇̇ONKÓW W CZASACH GRZEGORZA WIELKIEGO NA PODSTAWIE JEGO REGISTRUM EPISTULARUM ORAZ NORM PRAWA RZYMSKIEGO
}

Niniejszy tekst jest nawiązaniem i dopełnieniem do artykułu, który ukazał się w poprzednim numerze „Vox Patrum”, poświęconego ograniczeniom stanu w przyjmowaniu do klasztorów w czasach Grzegorza Wielkiego ${ }^{1}$. Niniejsza publikacja ma na celu omówienie problematyki związanej z przyjmowaniem do klasztorów osób, w stosunku do których ograniczenie nie rodzi się z dziedziczenia stanu przez urodzenie, lecz z przyjętego lub narzuconego zobowiązania. W tym przypadku chodzi o zobowiązanie do służby wojskowej lub zawarcie związku małżeńskiego ${ }^{2}$.

* Ks. dr Janusz Lewandowicz - wykładowca języków klasycznych w Wyższym Seminarium Duchownym w Łodzi; e-mail: janlew@wsd.lodz.pl.

${ }^{1}$ Por. J. Lewandowicz, Ograniczenia stanu jako przeszkoda w przyjmowaniu do klasztorów w czasach Grzegorza Wielkiego na podstawie jego „Registrum Epistularum” oraz norm prawa rzymskiego, VoxP 35 (2015) t. 64, 317-344.

${ }^{2}$ Spośród ogromnej literatury dotyczącej życia zakonnego zwracamy uwagę na następujące pozycje natury ogólnej uwzględnione w niniejszym artykule: O. Porcel, La doctrina monastica di san Gregorio Magno y la „Regula Monachorum”, Madrid 1951; R. Rudmann, Mönchtum und kirchlicher Dienst in den Schriften Gregors des Großen, St. Ottilien 1956; C.M. Figueras, De impedimentis admissionis in religionem usque ad decretum Gratiani, Scripta et documenta 9, Abbatia Montisserrati 1957; G.D. Gordini, Origine e sviluppo del monachesimo a Roma, „Gregorianum” 37 (1956) 220-260; O. Porcel, San Gregorio y el monacato. Cuestiones controverdidas, Monastica 1 = Scripta et Documenta 12, Abbatia Montisserrati 1960, 1-95; G. Jenal, Grégoire le Grand et la vie monastique dans l'Italie de son temps, w: Grégoire le Grand. Colloques Internationaux du Centre National de la Recherche Scientifique (Chantilly, Centre culturel Les Fontaines, 15-19 septembre 1982), éd. J. Fontaine - R. Gillet - S. Pellistrandi, Paris 1986, 147-157; F. Prinz, Das westliche Mönchtum zur Zeit Gregors des Grossen, w: Grégoire le Grand, s. 123-136; J. Leclercq, Spiritualità e cultura nel monachesimo del pieno medioevo, w: Cultura e spiritualità nella tradizione monastica, ed. G. Penco, Studia Anselmiana 103, Roma 1990, 105-128; Gregorio Magno e il suo tempo. XIX Incontro di studiosi dell'antichità cristiana in collaborazione con l'Ecole Française de Rome (Roma, 9-12 maggio 1990), Studia Ephemeridis „Augustinianum” 33/1-2, Roma 1991; K.L. Noetlichs, Das Kloster als „Strafanstalt” im kirchlichen und weltlichen Recht der Spätantike, „Zeitschrift der Savigny-Stiftung für Rechtsgeschichte" 111 (1994) 18-40; G. Penco, Il monachesimo fra spiritualità e cultura, Milano 1991; tenże, Storia del monachesimo in Italia: dalle origini alla fine del Medioevo, Milano 200233; 
1. Żołnierze. Za pontyfikatu Grzegorza Wielkiego przeszkody podobne do wynikających z ograniczeń stanu zaczęły obowiązywać pełniących służbę wojskowa. Czas jej trwania wynosił przynajmniej 25 lat, a w niektórych przypadkach nawet 40. Każdy, kto złożył przysięgę, mógł opuścić szeregi wojska dopiero po odbyciu służby. Początkowo żołnierze mieli swobodę w wyborze życia zakonnego. Informację o tym znajdujemy w liście do cesarza napisanym przez Grzegorza w sierpniu 593 r. Jest on reakcją na wprowadzone rok wcześniej przez Maurycjusza prawo ${ }^{3}$ zabraniające przyjmowania do klasztorów osób noszących znak na ręce (manu signati), czyli żołnierzy ${ }^{4}$. Celem prawa było przeszkodzenie w unikaniu służby wojskowej przez żołnierzy, którzy według ustawodawcy mogli wstępować do klasztoru z nieszczerych pobudek, tzn. nie z motywów wiary, lecz z chęci ucieczki przed zobowiązaniem do służby. Zgodnie z wymogiem imperatora żołnierz, który pragnął zostać mnichem, musiał mieć uregulowany stosunek do służby wojskowej. Jeśli był do niej zobowiązany, musiał najpierw ją odsłużyć, potem mógł starać się o przyjęcie do klasztoru, o ile nie został zwolniony wcześniej na skutek słabości fizycznej ${ }^{5}$. Wywołało to negatywną odpowiedź papieża. Uznał on, że zmiana prawa, które dotychczas na to pozwalało ${ }^{6}$, jest krzywdząca dla życia Kościoła.

Grzegorz miał świadomość, że mogły się zdarzać przypadki nieszczerych intencji. Uważał jednak, iż nie można wskutek tego poświęcać ludzi prawdziwie się nawracających. I choć uznawał zasadność ograniczeń w przypadku

G. Jenal, In cerca di ordine quando l'apocalisse sembra vicina: Gregorio Magno e il monachesimo del suo tempo in Italia, w: Gregorio Magno nel XIV centenario della morte. Convegno internazionale (Roma, 22-25 ottobre 2003), Atti dei Convegni Lincei 209, Roma 2004, 221-246; P. Pellegrini, Militia clericatus monachici ordines: istituzioni ecclesiastiche e società in Gregorio Magno, Testi e studi di storia antica 20, Catania 2008²; B. Müller, Gregory the Great and Monasticism, w: A Companion to Gregory the Great, ed. B. Neil - M. Dal Santo, Leiden 2013, 83-108.

${ }^{3}$ List III 61 (ed. D. Norberg, CCL 140, Turnholti 1982, 209), który o nim wzmiankuje, a następnie list VIII 10 (ed. D. Norberg, CCL 140A, Turnholti 1982, 527-528), przekazujący metropolitom treść tego prawa do zastosowania, nie zawierają daty promulgacji, której nie można ustalić inaczej jak z porównania treści listów Grzegorza, gdyż nigdzie indziej informacji o tym prawie Maurycjusza nie ma. W liście do Teodora, lekarza cesarskiego, papież pisze o cesarzu: „transacto anno talem in republica sua legem protulit” (Epistula III 64, CCL 140, 214). Zważywszy, że list datowany jest na sierpień 593 r. można ustalić, że prawo to wydane zostało przez Maurycjusza w roku 592. Poza Grzegorzem nie zachowały się wzmianki o tym prawie Maurycjusza.

${ }^{4}$ Przysięga wojskowa, jaką składano, pociaggała za sobą opatrzenie ręki znakiem przynależności do wojska, aby można było rozpoznać żołnierza w przypadku dezercji. Por. Opere di Gregorio Magno, V. Lettere, a cura di V. Recchia, t. 1, Roma 1996, 488, nota 9.

${ }^{5}$ Por. Gregorius Magnus, Epistula III 61, CCL 140, 210: „ei, qui semel in terrena militia signatus fuerit, nisi aut expleta militia, aut pro debilitate corporis repulsus, Christo militare non liceat".

${ }^{6}$ Por. Iustinianus, Novella V 2 (ed. R. Schoell - G. Kroll: Corpus iuris civilis, vol. 3: Novellae, Berolini 1895, 29-31), która odwołując się do Listu św. Pawła do Galatów $(3,28)$ pozwalała na wstępowanie do klasztorów zarówno niewolnikom, jak i wolnym (,sive liberii forte sive servi sint” - w. 22 i 26). Nie wspomina jednak o żołnierzach. Związany z nimi problem zakazu pojawia się dopiero za panowania Maurycjusza. 
pragnących wstapić do stanu duchownego, to droga życia mniszego przedstawiała dla niego zupełnie odmienną wartośćc ${ }^{7}$ Dzięki omawianiu ustawy w liście zachowała się dla nas jej istotna treść:

„I oto otwarcie się powiada, że temu, kto raz piętnem został naznaczony podczas ziemskiej żołnierki, nie wolno wstąpić w służbę żołnierską u Chrystusa, chyba po odsłużeniu wojska albo jeżeli zostanie wydalony ze służby z powodu ułomności fizycznej"s.

Jak dalece sprawa ta leżała Grzegorzowi na sercu świadczy dalsza treść listu. Papież sięga tu po argument ad personam wskazując pośrednio, że prawo takie wprowadził na krótko Julian Apostata9 ${ }^{9}$ Jakkolwiek nie znamy pełnej treści tego prawa, ani nie znajdujemy wzmianki o nim gdzie indziej niż w listach Grzegorza, to jednak aluzja, jaką czyni Grzegorz w liście do Maurycjusza nie wymieniając imienia Juliana ${ }^{10}$, musiała być czytelna: postępujesz jak wróg chrześcijan. Jej oczywistość wynika z listu do Teodora, lekarza cesarskiego, w którym Grzegorz prosi go o doręczenie listu adresowanego do cesarza, o którym pisze:

„Wydał bowiem rozkaz, że żaden urzędnik publiczny, żaden pomocnik setnika, nikt mający znak na ręce, albo ten kto zaliczony został w poczet żołnierzy, nie może wstąpić do klasztoru, chyba po odbyciu służby wojskowej. Takie prawo - jak twierdzą znawcy starodawnych praw - wydał pierwszy Julian, o którym wszyscy wiemy, jak wielkim był przeciwnikiem Boga"11.

Znaczące jest, że papież nie zgłaszał zastrzeżeń do zakazu wstępowania przez urzędników kurialnych w szeregi duchowieństwa. Postawę Grzegorza można zrozumieć, jeśli weźmie się pod uwagę, że trzeba było radykalnej odmiany życia, aby poświęcić się kontemplacji spraw Bożych przy jednoczesnej rezygnacji z udziału w życiu świata w ogołoceniu życia klasztornego. Droga takiej przemiany była jednak tym, co dla Grzegorza było najistotniejsze. Otwierała, jak sądził, ludzi zagrożonych w świecie na zbawienie. W słowach skierowanych bezpośrednio do Maurycjusza tak o tym mówi:

„W prawie tym dodane jest, że żadnemu człowiekowi noszącemu znak na ręce $^{12}$ nie wolno wstapić do stanu duchownego. Ustawy tej - wyznaję przed mymi Panami - zląkłem się niezmiernie, ponieważ przez nią zamyka się dla

\footnotetext{
${ }^{7}$ Por. Gregorius Magnus, Epistula III 61, CCL 140, 209-211.

${ }^{8}$ Tamże, CCL 140, 210: „Et ecce aperta uoce dicitur ut ei qui semel in terrena militia signatus fuerit, nisi aut expleta militia, aut pro debilitate corporis repulsus, Christo militare non liceat", thum. J. Czuj: Św. Grzegorz Wielki, Listy, t. 1, Warszawa 1954, 242.

9 Ślad takiego prawa nie zachował się nigdzie poza wzmianką w liście Grzegorza do lekarza cesarskiego Teodora. Por. tenże, Epistula III 64, CCL 140, 214-215.

${ }^{10}$ Por. tenże, Epistula III 61, CCL 140, 209.

${ }^{11}$ Tenże, Epistula III 64, CCL 140, 214.

${ }^{12}$ To znaczy żołnierzowi, ponieważ wojskowym wypalano znak na ręce będący świadectwem podlegania służbie, aby można było ich łatwo zidentyfikować.
} 
wielu ludzi drogę do nieba i zakazuje się im tego, co dotychczas wolno było czynić. Wielu bowiem jest takich, którzy mogą wieść życie duchowne nawet w stroju świeckim. I wielu jest takich, którzy mogą dostąpić zbawienia u Boga tylko wtedy, gdy wszystko opuszczą"13.

Zbawienie jest, według Grzegorza, motywem i podstawą wszelkich działań. Dlatego wysnuwa bezpośredni wniosek: „ta ustawa zwrócona jest przeciw Bogu, Stwórcy wszechrzeczy"14. Określa jednocześnie, jakie reguły winny decydować o kształtowaniu doczesnego porządku społecznego:

„Na to bowiem niebiosa dały miłościwym władcom ${ }^{15}$ władzę nad wszystkimi ludźmi, aby wspierali dążących do dobrego, by droga do nieba wiodąca stała się szerszą, by królestwo ziemskie służyło królestwu niebieskiemu"16.

$\mathrm{Z}$ punktu widzenia papieża, a według niego winno to być zagwarantowane w prawie imperium, służba Boża ma pierwszeństwo przed służbą państwu. Cesarz, którego władza pochodzi od Boga, nie może innych odciągać od służby Bogu.

Forma, w jakiej zwraca się do Maurycjusza, przybiera postać języka biblijnego i winna być odbierana przez adresata jako naznaczona boskim autorytetem:

„Ja cię z pisarza uczyniłem dowódcą straży przybocznej, z dowódcy straży przybocznej cezarem, z cezara imperatorem, i nie tylko to, ale nawet ojcem imperatorów. Kapłanów moich powierzyłem w twoje ręce, a ty swoich żołnierzy odciagasz od mojej służby. Odpowiedz - proszę - Najłaskawszy Władco, słudze swemu, co odpowiesz twojemu Panu, gdy przyjdzie i zapyta cię o to na Sądzie?"17.

Tak ostra reakcja Grzegorza wobec imperatora jest rzeczą niezwykłą, nawet jeśli zważyć, że wzajemne relacje cechowało pewne napięcie. Nigdzie więcej Grzegorz nie posuwa się do argumentacji, że cesarz, którego Bóg

${ }^{13}$ Gregorius Magnus, Epistula III 61, CCL 140, 209: „In qua lege subiunctum est ut nulli qui in manu signatus est converti liceat. Quam constitutionem ego, fateor dominis meis, vehementer expavi, quia per eam caelorum via multis clauditur, et quod nuncusque licuit, ne liceat prohibetur. Multi enim sunt qui possunt religiosam vitam etiam cum saeculari habitu ducere. Et plerique sunt, qui nisi omnia reliquerint, salvari apud Deum nullatenus possint”, tłum. Czuj, t. 1, s. 242.

${ }^{14}$ Tamże: „quia contra auctorem omnium deum hanc intendere constitutionem sentio”, tłum. Czuj, t. 1, s. 242.

${ }^{15}$ Liczba mnoga wynika stąd, że w 591 r. Maurycjusz przybrał sobie formalnie swego syna Teodozjusza na współrządcę imperium.

${ }^{16}$ Gregorius Magnus, Epistula III 61, CCL 140, 210: „Ad hoc enim potestas super omnes homines dominorum meorum pietati caelitus data est, ut qui bona appetunt adiuuentur, ut coelorum uia largius pateat, ut terrestre regnum caelesti regno famuletur", thum. Czuj, t. 1, s. 242.

${ }^{17}$ Tamże: „Ego te de notario comitem scubitorum, de comite scubitorum caesarem, de caesare imperatorem, nec solum hoc, sed etiam patrem imperatorum feci. Sacerdotes meos tuae manui commisi, et tu a meo seruitio milites tuos subtrahis. Responde rogo, piissime domine, seruo tuo, quid uenienti et haec dicenti responsurus es in iudicio Domino tuo?”, thum. Czuj, t. 1, s. 242-243. 
prowadził drogą kariery od pisarza do imperatora, nie ma prawa zabraniać służby Bogu nawróconym żołnierzom.

Z góry przyjęta ocena intencji wstępującego do klasztoru żołnierza jako uzasadnienie ustawy spotyka się również ze zdecydowanym sprzeciwem Grzegorza:

„Lecz może ktoś przypuszcza, że żaden z nich nie nawraca się z czystej intencji. A ja niegodny sługa wasz wiem, jak za dni moich wielu nawróconych żołnierzy w klasztorze dokonywało cudów, czyniło znaki i moce. A tu prawo zakazuje, by już nikt z nich nie mógł się nawrócić”18.

Podkreślanie motywu zbawienia było szczególnie uzasadnione, skoro papież żywił przekonanie, iż nieszczęścia tamtego czasu są zapowiedzią nadchodzącego nieuchronnie ostatecznego dnia ${ }^{19}$ :

„Bardzo godne jest zastanowienia, że właśnie w tym czasie zabrania się komuś opuścić świat, gdy zbliża się koniec świata"20.

Oczywiste było dla Grzegorza prawo Justyniana, którego Kodeks w ustawie z listopada $531 \mathrm{r}$. zakazywał porzucania stroju mniszego na rzecz wojskowego $^{21}$. Równie oczywiste było dla papieża to, że powinna istnieć możliwość zmiany stroju wojskowego na mniszy. Nic bowiem nie było dla niego w tamtej chwili tak istotne, jak służba Boża - Christo militare.

Mimo osobistego sprzeciwu Grzegorz rozesłał rozporządzenie augusta, o czym świadczy zakończenie listu:

„Ja wprawdzie spełniając rozkaz postarałem się, by prawo to zostało rozesłane na wszystkie strony świata, lecz ponieważ samo prawo zupełnie nie odpowiada woli Boga wszechmocnego, więc na piśmie zgłaszam Najjaśniejszym Władcom moje zastrzeżenia. Spełniłem więc podwójny obowiązek, bo i wobec władcy okazałem się posłusznym i nie zamilczałem tego, co uważam za należne Bogu"22.

${ }^{18}$ Tamże: „Sed fortasse creditur quia nullus eorum puro animo conuertatur. Ego indignus famulus uester scio quanti diebus meis in monasterio milites conuersi miracula fecerunt, signa et virtutes operati sunt. Sed per hanc legem iam ne quisquam talium conuerti ualeat prohibetur", thum. Czuj, t. 1, s. 243.

${ }^{19}$ Por. na ten temat rozdział IV książki R.A. Markus, Grzegorz Wielki, thum. P. Nehring, Warszawa 2003, 68-86, noszący znamienny tytuł: „Appropinquante mundi termino: starzejący się świat”.

${ }^{20}$ Gregorius Magnus, Epistula III 61, CCL 140, 210, thum. Czuj, t. 1, s. 243. Zaledwie cztery miesiące wcześniej pisał do duchowieństwa diecezji mediolańskiej: „Mundi igitur mala quae dudum uentura audiebamus, aspicimus; quasi paginae nobis codicum factae sunt ipsae iam plagae terrarum. In interitum ergo rerum omnium pensare debemus nil fuisse quod amauimus" (tenże, tenże, Epistula III 29, CCL 140, 175). Zob. też tenże, tenże, Epistula VII 26, CCL 140, 482: „Et uos, quare nescio, occupari desideratis? Cur enim, magnifice fili, non consideras quia mundus in fine est?"

${ }^{21}$ Por. CJ I 3, 52, 9, ed. P. Krueger: Corpus iuris civilis, vol. 2: Codex Iustinianus, Berolini $1877,36$.

${ }^{22}$ Gregorius Magnus, Epistula III 61, 210-211: „Ego quidem iussioni subiectus eandem legem per diuersas terrarum partes feci transmitti, et quia lex ipsa omnipotenti deo minime concordet ecce 
Kopia listu okólnego do metropolitów podległych Rzymowi nie zachowała się w Registrum ${ }^{23}$, jest jednak w zbiorze tego rodzaju list okólny zawierający normy wykonawcze do tej ustawy z listopada 597 roku:

„Postarałem się przesłać wam, Czcigodny Bracie, prawo, jakie wydał najłaskawszy imperator, aby ci, którzy są obowiązani do służby wojskowej lub publicznej, dla uniknięcia niebezpieczeństwa mogącego wyniknąć z ich zajęć nie przywdziewali stroju kościelnego ani nie wstępowali do klasztoru. Gorąco też napominamy, aby tych, którzy są zmazani zajęciami świeckimi, nie przyjmowano pochopnie do kleru kościelnego, bo jeśli w stroju kościelnym nie żyją inaczej, niż żyli, w takim razie nie starają się uciec przed światem, lecz tylko szukają odmiany"24.

Zwraca w tym liście uwagę to, że papież pisząc o przyjmowaniu do klasztorów żołnierzy zaleca ostrożność oraz staranne zbadanie ich dotychczasowego życia. Być może od wspomnianego listu do Maurycjusza zaszła w stanowisku cesarza jakaś zmiana. Nie ma jednak na to żadnych świadectw. Kiedy jednak nic nie stało na przeszkodzie, aby przyjąć do klasztoru byłego żołnierza, mimo swego pozytywnego nastawienia do takich przypadków, zalecał szczególną czujność we wspomnianym liście do podległych sobie metropolitów z sierpnia 597 roku:

„Jeśli zaś zgłaszają się do klasztorów wojskowi, nie można ich lekkomyślnie przyjmować bez uprzedniego dokładnego zbadania ich życia. Według normy zakonnej powinni oni w swym ubraniu być na próbie przez trzy lata, a potem dopiero za pomocą Bożą przywdziać strój mnisi. Jeśli w ten sposób zostaną wypróbowani i przyjęci i jeśli ze względu na swą duszę starają się pokutować za popełnione winy, nie należy im - dla ich życia i korzyści niebieskiej - odmawiać pobytu w klasztorze. Przeto - wierzcie mi - że i najjaśniejszy oraz najbardziej chrześcijański władca ze wszech miar zgadza się i chętnie przyjmuje chęć wstapienia do zakonu tych, o których wie, że nie są zajęci w służbie publicznej”25.

per suggestionis meae paginam serenissimis dominis nuntiaui. Vtrobique ergo quae debui exsolui, qui et imperatori oboedientiam praebui, et pro deo quod sensi minime tacui”, thum. Czuj, t. 1, s. 243.

${ }^{23}$ Por. Opere di Gregorio Magno, V. Lettere, t. 1, 490-491, nota 15.

${ }^{24}$ Gregorius Magnus, Epistula VIII 10, CCL 140A, 527: „Legem quam piissimus imperator dedit, ne fortasse hi qui militiae uel rationibus sunt publicis obligati, dum causarum suarum periculum fugiunt, ad ecclesiasticum habitum ueniant uel in monasteriis conuertantur, uestrae studui fraternitati transmittere, hoc maxime exhortans quod hi qui saeculi actionibus implicati sunt in clero ecclesiae propere suscipiendi non sunt; quia, dum in ecclesiastico habitu non dissimiliter quam uixerunt uiuunt, nequaquam student saeculum fugere sed mutare", tłum. J. Czuj, t. 3, Warszawa 1955, 20.

${ }^{25}$ Tamże, CCL 140A, 527-528: „Si qui uero ex militaribus numeris in monasteriis conuerti festinant, non sunt temere suscipiendi, nisi eorum uita subtiliter fuerit inquisita. Et iuxta normam regularem debent in suo habitu per triennium probari et tunc monachicum habitum deo auctore suscipere. Qui si ita sunt probati atque suscepti et pro anima sua paenitentiam de perpetratis culpis agere student, pro eorum uita et lucro caelesti non est eorum conuersio rennuenda. Qua de re etiam serenissimus et 
Z powyższego tekstu wynika, że w listopadzie 597 r. istniała jakaś możliwość przyjmowania do klasztorów żołnierzy. Być może chodzi o tych, którzy już wypełnili obowiązek służby. Być może też, że ograniczenia zostały w jakimś stopniu złagodzone. Pozostał jednak nadal zakaz przyjmowania urzędników.

Mimo tego zaangażowania papieża, aby umożliwić na wszelki sposób przyjmowanie do klasztorów żołnierzy, musiało to nastręczać jakichś trudności, które domagały się szczególnie ostrożnego traktowania takich przypadków. Przykład tego pozostawia nam list do Fortunata, biskupa Neapolu, z kwietnia roku 600. Grzegorz zastrzegł sobie w nim decyzje w sprawie przyjmowania do klasztoru ze stanu żołnierskiego i nakazywał zawiadamiać siebie o każdym takim przypadku ustanawiając tym samym szczególne normy dla Kampanii:

„Gdyby zaś zgłaszał się do klasztoru żołnierz, niech nikt się nie waży z jakiegokolwiek powodu przyjmować go bez naszej zgody, zanim będziemy o tym zawiadomieni" ${ }^{26}$.

Z listu, z którego pochodzi powyższy fragment wynika na pewno tyle, że przypadki żołnierzy traktował papież ze szczególną ostrożnością. Znamiona takiej postawy odnajdujemy już wcześniej. We wspomnianym liście z listopada 597 r. nakazywał Grzegorz nie udzielać im tonsury przed upływem trzyletniego okresu próby, podczas gdy w innych przypadkach stosowano okres dwuletni.

2. Związani węzlem małżeńskim. Liczba przypadków, w jakich porzucano życie w świecie, i gorliwość, jaka temu towarzyszyła, aby oddać się życiu mniszemu, nie omijały w pierwszych wiekach również stanu małżeńskiego. Nie dziwi więc, że prawo kościelne, jak i świeckie, musiało wkroczyć z przepisami regulującymi tego rodzaju przypadki, gdy kandydatami okazywali się ludzie związani węzłem małżeńskim. Pierwsza interwencja prawna została podjęta przez małoazjatycki synod w Gangrze ok. roku 340:

„Gdyby kobieta opuściła męża i chciała odejść od niego z pogardy dla małżeństwa, niech będzie wyklęta" ${ }^{27}$.

Kanon ten jest dowodem na to, że małżeństwo cieszyło się wielkim uznaniem ze strony Kościoła.

Konsekwencje dawnego systemu prawa rzymskiego „zastanego” po poprzednich cesarzach były dla władców chrześcijańskich niewygodne. Jakkolwiek nowi imperatorzy podzielali wraz z Kościołem zapatrywania na kwestię

christianissimus imperator, mihi credite, omnimodo placatur et libenter eorum conuersionem suscipit, quos in rationibus publicis implicatos non esse cognoscit", thum. Czuj, t. 3, s. 20.

${ }^{26}$ Tenże, Epistula X 9, CCL 140A, 835-836: „Miles uero si conuerti uoluerit, prius quam nobis renuntietur, nullus eum sine nostro consensu qualibet praesumat ratione suscipere", tłum. J. Czuj, t. 4, Warszawa $1955,14$.

${ }^{27}$ Concilium Gangrense (ca. 340) can. 14, ŹMT 37, [wyd. grecko-polskie, układ i opracowanie

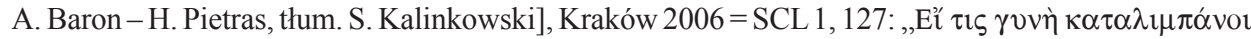

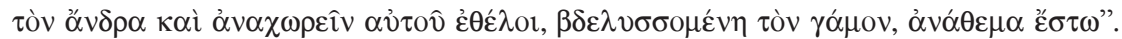


małżeństwa, musieli uwzględniać dotychczasowy stan prawny. Istotne znaczenie miały w tym przypadku względy majątkowe ${ }^{28}$.

Jeśli brać pod uwagę sytuację, w której przynajmniej jedno z małżonków chciało się udać na resztę życia do klasztoru, to małżeństwo stanowiło w tym względzie przeszkodę. Istniała jednak możliwość rozwiązania małżeństwa

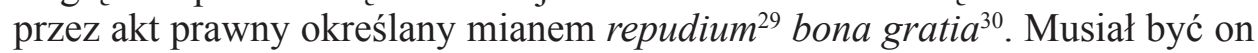
dokonany przez małżonka, który nie wybierał się do klasztoru. Konsekwencje prawne miały być analogiczne, jak w przypadku śmierci współmałżonka, i zostały przewidziane w Kodeksie Justyniana ${ }^{31}$. Uznawał on w nim prawo jednej ze stron wstąpienia na „lepszą” drogę (ad meliorem migrans viam), polegającą na życiu w czystości (sub castitate conversationem concupiscens). W tym przypadku nie było oczywiście stwierdzenia winy współmałżonka, jak to miało miejsce przy rozwiązaniu małżeństwa przez akt repudium propter iustam causam.

Wkrótce po promulgacji Kodeksu prawo Justyniana ponownie podjęło w Nowelach kwestię wstępowania małżonków do klasztoru. Aż trzy akty

${ }^{28}$ Regulowały je już ustalenia Kodeksu Justyniana, który nakazywał zwrot posagu wniesionego przez małżonkę w przypadku rozwiązania małżeństwa przez męża.

${ }^{29}$ Repudium było jednostronnym aktem oddalenia współmałżonka i wypowiedzeniem umowy małżeńskiej. Informację na ten temat znajdujemy w Iustiniani Digesta XXIV 2, 1, ed. Th. Mommsen: Corpus iuris civilis, vol. 1: Institutiones, Digesta, Berolini 1872, 319: „Divortium autem vel a diversitate mentium dictum est vel quia in diversas partes eunt, qui distrahunt matrimonium. In repudiis autem, id est renuntiatione, comprobata sunt haec verba: «tuas res tibi habeto»; item haec: «tuas res tibi agito»”. Różniło się ono od rozwodu (divortium) tym, że rozwód był aktem o charakterze dwustronnym. Divortium było dozwolone w prawie Justyniana jedynie propter castitatem. Można się domyślać, że chodzi tu o rozwiązanie małżeństwa przez rozwód, kiedy małżonkowie zamierzają wstąpić do klasztoru. Dokładną analizę terminu repudium i jego pojęcia daje S.P. Kursa, Repudium i jego skutki prawne w świetle kodyfikacji Justyniana, „Czasopismo prawno-historyczne” 64 (2012) z. 2, 61-80. Zob. też L. Caes, La terminologie du divorce dans les textes juridiques latins et les constitutions grecques de Justinien, w: Scrinium Lovaniense. Mélanges historiques Etienne Van Cauwenbergh, Gembloux - Louvain 1961, 167-180.

${ }^{30}$ Por. Kursa, Repudium, s. 58.

${ }^{31}$ Por. CJ I 3, 52, 15, ed. Krueger, s. 36-37: „Praeterea sancimus, sive vir solitariam vitam eligere velit sive mulier viro relicto ad exercitationem monachicam venerit, ne hoc ipsis poenae causa sit, sed propria omnimodo recipiant, ut mulieri dotem suam, coniugi ante nuptias donationem recipere liceat, lucrum autem ex his non quasi repudium intercesserit vindicetur vel remaneat apud eum qui non renuntiaverit, sed ex pacto quod in mortis casum initum est, quasi is qui a convictu recedat in matrimonio mortuus esse videtur, quoniam cohabitanti plane inutilis est: et acceptis iis, quae dotalibus instrumentis continentur de eo quod in casum mortis debeatur reliqua remittat ei qui religiosam vitam elegit: ne tamen mulier audeat ante annum elapsum ad aliud matrimonium spectare propter generationis incertum: sed si tale quid futurum sit, repudium quod «bona gratia» dicunt mittatur ab eo qui religiosam vitam non elegerit, et sic faciat quod velit, lucris secundum praedictum modum ad eum devolutis. eo videlicet, quod ex huiusmodi causis lucratur, omnimodo, et si vel uxor vel vir in priore matrimonio perseveret, liberis communibus ex hoc matrimonio progenitis, si qui fuerint, conservando" [podkr. JL]. 
prawne wprowadzone w latach 535, 542 i 546 świadczą o żywotności proble$\mathrm{mu}^{32}$. Na pierwszym miejscu w noweli XXII wymienia się jako powód repudium bona gratia - wstapienie współmałżonka do klasztoru. Dokonanie tego aktu umożliwiało drugiej stronie ponowne zawarcie małżeństwa ${ }^{33}$. Przywdzianie habitu, podobnie jak w przywołanym wyżej fragmencie Kodeksu, było w tym przypadku traktowane analogicznie jak śmierć i pozwalało na konsumowanie ewentualnych korzyści wynikających z umów małżeńskich zawartych mortis causa ${ }^{34}$. Ustawa obligowała ponadto do złożenia „niewielkiego” zadośćuczynienia współmałżonkowi przez stronę wybierającą życie zakonne ${ }^{35}$.

Warto zwrócić uwagę, że podjęcie życia w klasztorze mogło się dokonać mimo albo wbrew woli kobiety, jeżeli dokonałaby ona oddalenia małżonka przez repudium sine causa, czyli bez uzasadnionej przyczyny. W takim razie bowiem prawo noweli CXVII z 542 r. nakazywało zamknięcie takiej kobiety do końca życia w klasztorze, który miał być wyznaczony przez biskupa miejsca zamieszkania małżonków. Jej majątek zaś z mocy prawa przechodził w dwóch trzecich na wspólne dzieci i w jednej trzeciej na rzecz klasztoru. Miało to zapobiec porzucaniu małżeństwa dla podjęcia rozwiązłego życia ${ }^{36}$. W 14 lat później w roku 556 Justynian wyrównał dysproporcje między skutkami dokonania repudium sine iusta causa w przypadku męża i żony, i w noweli CXXXIV

${ }^{32}$ Por. Iustinianus, Novella XXII 5; tamże CXVII 12-13; tamże CXXIII 40.

${ }^{33}$ Por. Kursa, Repudium, s. 58. Zob. też M. Wójcik, Wstapienie do klasztoru jako przyczyna ustania malżeństwa $w$ prawie rzymskim, w: Wokót problematyki matżeństwa w prawie rzymskim. Henrico Insadowski (1888-1946) in memoriam, red. A. Dębiński-M. Wójcik, Lublin 2007, 171-190.

${ }^{34}$ Por. Iustinianus, Novella XXII 5, ed. Schoell - Kroll, s. 150: ,hoc habere oportet eum qui dimittitur ab altero, sive vir sive mulier sit, eo quod et iste quantum ad matrimonium videtur mori, aliud pro alio vitae eligens iter". Zob. B. Biondi, Il diritto romano cristiano, t. 3, Milano 1954, 181.

${ }^{35}$ Por. Iustinianus, Novella XXII 5, ed. Schoell - Kroll, s. 150: „Tunc enim lex et alia nostra dicit licentiam esse viro et mulieri ad meliora migranti transigere matrimonium et abscedere, quodam brevi dimisso solacio ei qui relinquitur".

${ }^{36}$ Posag wniesiony również przechodził na dzieci, a gdy ich nie było - na męża. W przypadku braku dzieci dwie trzecie przechodziły na klasztor, a jedna trzecia na wstępnych. Gdy nie było ani zstępnych ani wstępnych, cały majątek przypadał klasztorowi. Por. tamże CXVII 13, ed. Schoell - Kroll, s. 562-563: „Quia vero quaedam mulieres inhoneste volentes vivere festinant propria matrimonia solvere, sancimus, si quando mulier circa aliquam praedictarum a nobis causarum voluerit mariti solvere matrimonium, licentiam quidem eam non habere hoc agere, si vero permanserit in huiusmodi impia voluntate et repudium marito transmiserit, iubemus dotem quidem viro dari communibus filiis secundum legem servandam, si autem filios non habuerit, lucrum fieri marito, mulierem vero periculo iudicis negotium audientis tradi episcopo civitatis in qua communiter domicilium habuerunt, quatenus illius providentia in monasterium ipsa mittatur, ut debeat donec advixerit ibi consistere. Et si quidem filios habuerit huiusmodi mulier, duas partes propriae eius substantiae dari filiis, tertiam vero monasterio in quo mittitur applicari iure proprietatis; si vero filios non habuerit, sunt autem ei parentes, duas quidem partes eius substantiae monasterio praeberi ubi mittitur, tertiam vero partem illius parentibus dari, nisi tamen sub potestate eam habentes inrationabili repudio consenserunt: in hoc enim consentientes nihil eos penitus ex substantia filiae habere permittimus, sed haec omnia venerabili monasterio volumus applicari; porro neque filiis neque parentibus existentibus ei omnem similiter eius substantiam competere monasterio". 
nakazywał, aby mężczyzna i kobieta ponosili w przypadku nieuzasadnionego oddalenia współmałżonka jednakowe skutki, to znaczy dożywotnie osadzenie $\mathrm{w}$ klasztorze z poniesieniem stosownych konsekwencji majątkowych ${ }^{37}$.

W 546 r. Justynian uznał, że wstąpienie jednej ze stron do klasztoru pociąga za sobą automatyczne rozwiązanie węzła z mocy prawa bez wymagania nawet zachowania formy prawnej wypowiedzenia umowy małżeńskiej (poprzez akt repudium $)^{38}$. Jak wynika z noweli CXXIII momentem, który pociągał za sobą skutki prawne było otrzymanie stroju zakonnego jako zewnętrznego wyrazu włączenia do stanu mniszego. Strony były wówczas zobowiązane do zwrotu posagu i zadatku zaręczynowego ${ }^{39}$.

Z takim stanem prawnym mamy do czynienia w okresie pontyfikatu Grzegorza. Listy pozwalają porównać stosowaną przez niego praktykę z obowiązującymi normami świeckimi.

Jeśli jedno z małżonków pragnęło wstapić do klasztoru, mogło to zrobić pod warunkiem, że drugie również do klasztoru wstapi. Dla Grzegorza warunek taki wynikał z trwania węzła małżeńskiego. Do wstąpienia wymagana była

${ }^{37}$ Por. tamże CXXXIV 11, 1, ed. Schoell - Kroll, s. 686: „Si vero praeter a nobis definitas causas praesumpserint aliqui solvere matrimonium, iubemus, si quidem descendentes habuerint sive ex ipso sive ex alio matrimonio, substantiam eorum illis dari secundum legem ordinem, et tam virum quam mulierem in monasterium mitti in omnibus vitae suae temporibus, et de singulorum facultatibus quaternas uncias monasteriis in quibus mittuntur separari; viro nihilo minus neque usum habente datae partis filiis. Si vero descendentes non habeant, sed ascendentes inveniantur, tertiam partem substantiae accipere eos, si non iniquitati solutionis matrimonii consenserint, duas vero partes monasteriis in quibus unusquisque mittitur separari”.

${ }^{38}$ Stanowi tak Justynian, regulując jednocześnie postępowanie dotyczące prawa majątkowego. Por. Iustinianus, Novella CXXIII 40, ed. Schoell - Kroll, s. 622: „Si vero constante adhuc matrimonio aut vir solus aut uxor sola intraverit in monasterium, solvatur matrimonium et citra repudium, postquam tamen persona pergens ad monasterium schema perceperit. Et si quidem vir elegerit monachicam vitam, restituat mulieri post dotem etiam si quid aliud ab ea perceperit, et super haec ex nuptiali donatione tantam partem, quanta ex morte viri competebat mulieri secundum pactum dotalibus instrumentis insertum. Si vero mulier fuerit in monasterio ingressa, simili modo retineat vir nuptialem donationem et casum dotis ex morte mulieris placitum, reliquum vero dotis mulieri restitui praecipimus, et si quid aliud ex rebus mulieris apud eum inveniatur. Ambobus autem monachicam vitam eligentibus iubemus vacantibus dotalibus placitis virum retinere donationem nuptialem et mulierem propriam accipere dotem et quicquid aliud viro dedisse probetur, ut unusquisque citra damnum suis fruatur rebus; nisi forte sponsus sponsae aut sponsa sponso aut maritus uxori aut uxor marito donare aliquid aut cedere voluerit".

${ }^{39}$ Por. tamże CXXIII 39, ed. Schoell - Kroll, s. 622: „Sponsalibus quoque secundum leges factis inter aliquos, sive sponsus in monasterium ingrediatur, recipiat quae pro sponsalibus arrarum nomine data sunt, sive sponsa monachicam vitam elegerit, illa solummodo reddat quae similiter arrarum nomine accepit, poena utrique parti concedenda". Wspomina o tym również wcześniej Iustinianus, Novella V 5, ed. Schoell - Kroll, s. 32-33: „Si autem uxorem habetis, deinde eam relinquens in monasterium ingrediatur, et dos mulieri servetur et ex morte pactum, quod in alia nostra sanximus constitutione; omnibus, quae super monachis de his dicta sunt, et in mulieribus in monasterio ingredientibus valituris" oraz przepis Kodeksu występujący jedynie w wersji greckiej: CJ I 3, 52, 15, ed. Krueger, s. 36-37. 
zatem nie tylko sama zgoda współmałżonka. Musiał on również iść do klasztoru, aby nie być w świecie narażonym na niebezpieczeństwo niedochowania wierności małżeńskiej. Świadectwo tego rodzaju praktyki przynosi list papieża do Urbika, opata klasztoru św. Hermesa w Panormos, z lipca 596 roku:

„oddawca niniejszego listu Agaton, pragnie wstąpić do klasztoru [...]. Wiedz jednak, że należy go przyjąć pod tym warunkiem, że i jego żona również zechce wstapić do klasztoru. Dopóki bowiem przez połączenie dwojga jedno jest ciało małżeńskie, niewłaściwe jest, aby część jego szła do klasztoru a część zostawała na świecie"

Grzegorz był świadom różnicy wymagań, jakie stawiał on, i tych, jakie określało prawo cesarskie. Wspomina o tym w liście z lutego $601 \mathrm{r}$. uznając, że czego dozwala to ostatnie (mundana lex), na to nie zezwala prawo boskie (lex divina):

„Jeśli prawo świeckie stwierdza, że ze względu na pójście do klasztoru małżeństwo może być rozwiązane bez zgody którejś ze stron, to jednak prawo boskie nie dozwala, aby się tak działo" ${ }^{4}$.

List ten zawiera jeden z nielicznych przypadków, kiedy Grzegorz nie idzie dokładnie za normą cesarską, lecz zaostrza ją odwołując się do prawa Bożego. Jedyną okolicznością, kiedy współmałżonek mógł jednostronnie podjąć decyzję o zamknięciu się w klasztorze, była zdrada małżeńska. Mąż mógł wówczas, jak wynika z powyższego listu ${ }^{42}$, opuścić żonę i przywdziać habit.

Powyższe informacje natury ogólnej znalazły się we wspomnianym liście ze względu na potrzebę ich aplikacji do konkretnego przypadku. Niejaka Agatoza wniosła bowiem do papieża zażalenie, iż wbrew jej woli przyjęto jej męża do klasztoru prowadzonego przez opata Urbika ${ }^{43}$. Grzegorz stwierdza jednak, iż nie godzi się przyjmować kandydata, który ciągle jest związany węzłem z żoną. Musiał to być akt obopólny. Zachodziło jednak podejrzenie, że taki akt mógł się dokonać. Dlatego papież nakazuje uprzednie zbadanie,

${ }^{40}$ Gregorius Magnus, Epistula VI 49, CCL 140, 422, thum. J. Czuj, t. 2, Warszawa 1954, 221: „Quia igitur Agatho lator praesentium in monasterio dilectionis tuae conuerti desiderat [...]. Quem tamen ita suscipiendum esse cognosce, si et uxor ipsius similiter conuerti uoluerit. Nam dum unum utrorumque corpus coniugii copulatione sit factum, incongruum est partem conuerti et partem in saeculo remanere".

${ }^{41}$ Tenże, Epistula XI 30, CCL 140A, 919: ,etsi mundana lex praecipit conversionis gratia utrolibet invito solvi posse coniugium, divina haec lex fieri non permittit", tłum. własne.

${ }^{42}$ Por. tamże.

${ }^{43} \mathrm{Z}$ rozproszonych po listach wiadomości (por. tenże, Epistula II 50; V 4; VI 41; VI 49; IX 20-21; XI 30) można wywnioskować, że Urbik był opatem klasztoru św. Hermesa na Sycylii. Był to jeden z sześciu klasztorów, które Grzegorz miał ufundować na Sycylii z własnego majątku, zanim został papieżem. Informacje na ten temat: Gregorius Turonensis, Historiarum libri X 1, ed. B. Krusch - W. Levison, MGH Scriptores rerum Merovingicarum I/1, Hannoverae 1951², 477-478, thum. K. Liman - T. Richter: Grzegorz z Tours, Historie. Historia Franków, wstęp, oprac. i komentarz D.A. Sikorski, Kraków 2002, 417. 
czy przyjęcie męża Agatozy nie wiązało się z jej wcześniejszą zgodą, którą być może usiłuje ona odwołać lub ukryć. W takim razie Grzegorz nakazuje pozostanie męża w klasztorze i nakłonienie żony do wstąpienia na drogę życia mniszego. W tym przypadku, podobnie jak w innym liście do opata Urbika, uwydatnia się usilne staranie Grzegorza, aby propagować życie zakonne:

„Zwracamy uwagę, byś go przyjął z całą słodyczą i życzliwością i nieustannymi zachętami podsycał jego pragnienie żywota wiecznego oraz pilnie starał się zabiegać około zbawienia jego duszy, aby o ile pod twym kierownictwem wytrwa pobożnie w służbie Boga wszechmocnego, i jemu mogło wyjść na pożytek porzucenie świata, i tobie przysporzyć zasług jego nawrócenie" ${ }^{44}$.

Również i z tego listu wynika, że Grzegorz umożliwia wstapienie do klasztoru za zgodą obu stron, tylko wówczas, gdy obie strony obierają życie w klasztorze, względnie w przypadku zdrady małżeńskiej.

W przypadku ograniczeń wynikających z trwania węzła małżeńskiego na uwagę zasługuje ewolucja ustawodawstwa, uwzględniająca zobowiązania wynikające z chrześcijańskiego postrzegania małżeństwa i jego nierozerwalności, w odróżnieniu od małżeńskiego prawa rzymskiego, które stanowili jeszcze władcy pogańscy. Nowe prawo nie zezwalało na oddalenie współmałżonka sine causa nawet w przypadku chęci udania się do klasztoru.

W Kodeksie Justyniana promulgowane zostało prawo z roku 534 regulujące postępowanie w przypadkach, gdyby po zaręczynach i wymianie zadatków (arra), związanych z zamierzonym zawarciem małżeństwa, któraś ze stron zdecydowała się na wstąpienie do klasztoru ${ }^{45}$. Określało ono, że w przypadku odstąpienia od zawarcia małżeństwa z powodu wyboru życia zakonnego strony nie są związane wzajemnymi zobowiązaniami, choćby zostały już usta-

${ }^{44}$ Gregorius Magnus, Epistula VI 49, CCL 140, 422, thum. Czuj, t. 2, s. 221.

${ }^{45}$ Por. CJ I 3, 54, pr.-4, ed. Krueger, s. 56: „Deo nobis auxilium praebente omnia, quae pro honore sanctae catholicae ecclesiae ad dei placitum fieri properamus, legibus constituere et operibus adimplere desideramus. Et iam quidem multa cum eius auxilio statuimus, quae ecclesiasticae doctrinae statui conveniunt, in praesenti autem hoc pia deliberatione duximus corrigendum, quod hactenus contra dei timorem fiebat. Cognitum etenim nobis est, quod, si quis sponsus vel sponsa post datas aut acceptas arras voluisset se divino deputare servitio et a saeculari conversatione recedere ac sanctimonialem vitam vivere atque in dei timore permanere, compellebatur vir quidem ea quae arrarum nomine dederat amittere, sponsa vero duplum id quod acceperat reddere. quod nostrae mansuetudini satis religioni esse contrarium visum est. Unde per praesentem legem in perpetuum valituram iubemus, ut, si quis sponsus vel sponsa desideraverit saeculi istius vitam contemnens in sanctimonialium conversatione vivere, sponsus quidem omnia, quae arrarum nomine futuri causa coniugii dedisset, sine ulla imminutione recipiat, sponsa autem non duplum, sicut hactenus, sed hoc tantum sponso restituat, quod arrarum acceperat nomine, et nihil amplius reddere compellatur, nisi quod probata fuerit accepisse. Nam et maritis et uxoribus qui saeculo renuntiant iam anteriore lege a nobis provisum est, ut, sive maritus sive uxor religionis causa a coniugio recesserit et solitariam vitam elegerit, unusquisque eorum res suas recipiat, quas vel pro dote vel ante nuptias donatione praestiterat, et hoc tantummodo lucri nomine consequatur ab eo qui solitariam vitam elegerit, quod debuit legitime vel ex pacto per casum mortis exigere". 
lone i podjęte. Kodeks wspomina bowiem o stosowaniu do czasu jego promulgowania przepadku na rzecz narzeczonej wpłaconego przez narzeczonego zobowiązania, gdy decydował się na zerwanie zaręczyn i wstąpienie do klasztoru. Gdy taki krok podejmowała narzeczona, wypłacała na rzecz oblubieńca w dwójnasób to, co od niego otrzymała. Justynian zakazuje dotychczasowej praktyki i postanawia, że jeśli któreś z narzeczonych zapragnie opuścić świat i żyć w stroju mniszym, to narzeczony otrzymać ma z powrotem bez żadnej straty to, co wpłacił ze względu na planowane zawarcie związku małżeńskiego, narzeczona zaś winna zwrócić narzeczonemu to, co otrzymała tytułem zadatku - już nie w dwójnasób, ale w wysokości, w jakiej zadatek otrzymała.

Rozwiązanie takie odpowiada wydanemu wcześniej prawu stwierdzającemu, że w przypadku odstapienia jednej ze stron od umowy małżeńskiej ze względu na wybór życia zakonnego każda ze stron otrzymuje z powrotem to, co wniosła tytułem zadatku bądź posagu ${ }^{46}$. Usuwało ono zarazem przeszkodę narzeczeństwa ${ }^{47}$ przy wstępowaniu do klasztoru.

Grzegorz powołuje się w swojej korespondencji na powyższe prawo o nieponoszeniu konsekwencji z tytułu odstapienia od zawarcia małżeństwa ze względu na decyzję o wstappieniu do klasztoru. W jednobrzmiących listach ${ }^{48}$ wysłanych do Fortunata, biskupa Neapolu, oraz Antemiusza, zarządcy dóbr w Kampanii, porusza sprawę narzeczonej niejakiego Stefana, która wstapiła do klasztoru, gdy tymczasem niedoszły mąż zatrzymuje jej dom wraz z jakimiś rzeczami. Papież powołując się w tym przypadku na treść wspomnianego prawa (CJ I 3, 54, pr.-4) stwierdza, że nie może ona ponosić z tego tytułu żadnej szkody, a narzeczony zatrzymuje jej majątek nieprawnie.

W tonie listu Grzegorza daje się zauważyć uznanie dla tego rodzaju rozwiązania. Dopóki bowiem małżeństwo formalnie nie było zawarte, nie istniała przeszkoda węzła, która z punktu widzenia papieża była w takich przypadkach istotna. Wspomniane prawo zaczęło obowiazywać na Zachodzie po promulgacji per partes Italiae w roku 554 Kodeksu Justyniana oraz jego Nowel.

${ }^{46}$ Por. tamże I 3, 52, 15, ed. Krueger, s. 36-37.

${ }^{47}$ Por. Figueras, De impedimentis admissionis in religionem usque ad decretum Gratiani, s. $95-96$.

${ }^{48}$ Por. Gregorius Magnus, Epistula VII 20, CCL 140, 471: „Catellus praesentium lator nobis innotuit sororem suam, quae Stephano cuidam fuerat desponsata, diuinae propitiationis instinctu Neapolim in monasterio esse conuersam atque eundem Stephanum domum et res eius aliquas indebite detinere. Et quia decreta legalia desponsatam, si conuerti uoluerit, nullo omnino censuerunt damno multari, fraternitas tua una cum Anthemio subdiacono ueritatem diligenti curiositate studeat perscrutari. Et si, ut edocti sumus, domum uel quid aliud superscriptum Stephanum iniuste tenere cognoscitis, eum adhortatio uestra instanter admoneat ut quae indebite detinet sine aliqua mora uel altercatione restituat, ne rerum alienarum restitutionem sub qualibet excusationis specie differat. Quem si adhortationem uestram neglegere fortasse cognoscitis, nobis tam hoc quam etiam qualiter se causae ueritas habeat subtiliter indicate, quatenus cognito negotii merito aliter cogatur aequitate suadente restituere, quod facere propria sponte honestatis consideratione contemnit". 
W działalności św. Grzegorza Wielkiego, której obraz wyłania się z Listów papieża, daje się wyraźnie zauważyć jego usilne staranie o rozwój życia zakonnego. Przy każdej sposobności starał się on sprzyjać zamiarom ludzi wstapienia do klasztoru, usiłując usuwać ewentualne przeszkody. Mogły być nimi okoliczności życiowe albo przepisy prawa. W tym ostatnim przypadku nie wahał się sprzeciwić imperatorowi Maurycjuszowi, który wprowadził nowe ograniczenia. Odniesienie papieża do zarządzeń cesarza nie polegało jednak na ich kontestacji. Papież nakazywał je stosować, mimo iż z nimi się nie zgadzał.

Kilkakrotne odniesienie się do sytuacji, w których przedmiotem zainteresowania są małżonkowie wstępujący do klasztorów pozwala stwierdzić, że Grzegorz starał się stosować przede wszystkim do norm, jakie przyjmował Kościół, i uznawał je za wiążące dla chrześcijan nawet wówczas, gdy prawo cesarskie nie stawiało tak restrykcyjnych wymagań.

W poczynaniach Grzegorza Wielkiego ujawnia się wyjątkowo pozytywny stosunek do tej uprzywilejowanej w jego oczach formy życia chrześcijańskiego, jaką stanowiło życie zakonne. Działania te wytyczyły drogi na przyszłość w podejściu do życia zakonnego i znacząco wpłynęły na rozwój monastycyzmu i rolę, jaką odegrał on w późniejszym czasie na Zachodzie.

\section{ADMITTING TO MONASTERIES \\ PEOPLE OBLIGED TO MILITARY SERVICE OR BOUND BY MARRIAGE AT THE TIME OF ST. GREGORY THE GREAT BASED ON HIS REGISTRUM EPISTULARUM AND NORMS OF ROMAN LAW}

\section{(Summary)}

The paper discusses the obstacles existing in both secular law and practice of the Church, in the time of St. Gregory the Great, for joining the monastery by people performing the military service or bound in marriage. Subsequently, the paper indicates higher requirements, compared with secular law, imposed by the pope on people wanting to join the monastery but bound by marriage.

Key words: St. Gregory the Great, Registrum epistularum, letters, Roman law, Code of Theodosius, Justinian Code, Novels, monasticism, admission to monasteries, soldiers, bond of marriage, repudium.

Słowa kluczowe: Grzegorz Wielki, Registrum epistularum, listy, prawo rzymskie, Kodeks Teodozjusza, Kodeks Justyniana, Nowele, monastycyzm, przyjmowanie do klasztorów, żołnierze, węzeł małżeński, repudium. 


\section{BIBLIOGRAFIA}

\section{Źródła}

Concilium Gangrense (ca. 340), ed. A. Baron - H. Pietras, ŹMT 37, Kraków 2006 = SCL 1, 123-128.

Corpus iuris civilis, vol. 1: Institutiones, ed. P. Krueger, Digesta, ed. Th. Mommsen, Berolini 1872; vol. 2: Codex Iustinianus, ed. P. Krueger, Berolini 1877, vol. 3: Novellae, ed. R. Schoell - G. Kroll, Berolini 1895.

Gregorius Magnus, Registrum epistularum, ed. D. Norberg, CCL 140-140A, Turnholti 1982; tłum. włoskie a cura di V. Recchia: Opere di Gregorio Magno, V. Lettere, ed. D. Norberg, t. 1-4, Roma 1996-1999; tłum. J. Czuj: Św. Grzegorz Wielki, Listy, t. 1-4, Warszawa 1954-1955.

Gregorius Turonensis, Historiarum libri, ed. B. Krusch - W. Levison, MGH Scriptores rerum Merovingicarum I/1, Hannoverae 1951²; thum. K. Liman - T. Richter: Grzegorz z Tours, Historie. Historia Franków, wstęp, opracowanie, komentarz D.A. Sikorski, Kraków 2002.

\section{Opracowania}

Biondi B., Il diritto romano cristiano, t. 1-3, Milano 1952-1954.

CAEs L., La terminologie du divorce dans les textes juridiques latins et les constitutions grecques de Justinien, w: Scrinium Lovaniense. Mélanges historiques Etienne Van Cauwenbergh, Gembloux - Louvain 1961, 167-180.

Figueras C.M., De impedimentis admissionis in religionem usque ad decretum Gratiani, Scripta et documenta 9, Abbatia Montisserrati 1957.

Gordini G.D., Origine e sviluppo del monachesimo a Roma, „Gregorianum” 37 (1956) 220-260.

Gregorio Magno e il suo tempo. XIX Incontro di studiosi dell'àntichità cristiana in collaborazione con l'Ecole Française de Rome (Roma, 9-12 maggio 1990), Studia Ephemeridis „Augustinianum” 33/1-2, Roma 1991.

JEnal G., Grégoire le Grand et la vie monastique dans l'Italie de son temps, w: Grégoire le Grand. Colloques Internationaux du Centre National de la Recherche Scientifique (Chantilly, Centre culturel Les Fontaines, 15-19 septembre 1982), éd. J. Fontaine - R. Gillet - S. Pellistrandi, Paris 1986, 147-157.

JENAL G., In cerca di ordine quando l'apocalisse sembra vicina: Gregorio Magno e il monachesimo del suo tempo in Italia, w: Gregorio Magno nel XIV centenario della morte. Convegno internazionale (Roma, 22-25 ottobre 2003), Atti dei Convegni Lincei 209, Roma 2004, 221-246.

KuRsa S.P., Repudium i jego skutki prawne w świetle kodyfikacji Justyniana, „Czasopismo prawno-historyczne" 64 (2012) z. 2, 61-80.

LeclercQ J., Spiritualità e Cultura nel Monachesimo del Pieno Medioevo, w: Cultura e Spiritualità nella Tradizione Monastica, ed. G. Penco, Studia Anselmiana 103, Roma 1990, 105-128.

Markus R.A., Grzegorz Wielki, thum. P. Nehring, Warszawa 2003. 
Müller B., Gregory the Great and Monasticism, w: A Companion to Gregory the Great, ed. B. Neil - M. Dal Santo, Leiden 2013, 83-108.

Noetlichs K.L., Das Kloster als „Strafanstalt” im kirchlichen und weltlichen Recht der Spätantike, „Zeitschrift der Savigny-Stiftung für Rechtsgeschichte” 111 (1994) 18-40.

Pellegrini P., Militia clericatus monachici ordines: istituzioni ecclesiastiche e società in Gregorio Magno, Testi e studi di storia antica 20, Catania $2008^{2}$.

Penco G., Il monachesimo fra spiritualità e cultura, Milano 1991.

Penco G., Storia del monachesimo in Italia: dalle origini alla fine del Medioevo, Milano $2002^{3}$.

Porcel O., La doctrina monastica di san Gregorio Magno y la „Regula Monachorum”, Madrid 1951.

Porcel O., San Gregorio y el Monacato. Cuestiones Controverdidas, Monastica 1 = Scripta et Documenta 12, Abbatia Montisserrati 1960.

PRINZ F., Das westliche Mönchtum zur Zeit Gregors des Grossen, w: Grégoire le Grand. Colloques Internationaux du Centre National de la Recherche Scientifique (Chantilly, Centre culturel Les Fontaines, 15-19 septembre 1982), éd. J. Fontaine - R. Gillet - S. Pellistrandi, Paris 1986, 123-136.

Rudmann R., Mönchtum und kirchlicher Dienst in den Schriften Gregors des Großen, St. Ottilien 1956.

Wóscik M., Wstapienie do klasztoru jako przyczyna ustania matzeństwa w prawie rzymskim, w: Wokół problematyki matżeństwa w prawie rzymskim. Henrico Insadowski (1888-1946) in memoriam, red. A. Dębiński - M. Wójcik, Lublin 2007, 171-190. 